Article

\title{
Personality Traits and Behavioral Sleep Patterns: Differences between Men and Women
}

\author{
Victor Hugo Dias Pereira \\ Orcid.org/0000-0001-6942-7369 \\ Luiz Henrique de Carvalho Diniz Melo \\ Orcid.org/0000-0002-4461-6267 \\ Natanael Antonio dos Santos \\ Orcid.org/0000-0001-7708-9929 \\ Melyssa Kellyane Cavalcanti Galdino \\ Orcid.org/0000-0001-7180-3458 \\ Michael Jackson Oliveira Andrade* \\ Orcid.org/0000-0002-2650-451X
}

Universidade Federal da Paraíba, João Pessoa, PB, Brasil

\begin{abstract}
This study aimed to investigate the behavioral effects of sleep on the personality traits of young adults. The sample consisted of 114 volunteers with ages between 18 and 40. The subjects were characterized into three groups according to Horne and Östberg (1975): Moderately Morning ( $n=23)$; intermediary $(n=52)$ and Moderately Evening $(n=39)$. The Horne and Östberg Morningness and Eveningness questionnaire and the Big Five Personality Inventory were used for data collection. MANOVA showed a significant difference between the chronotype and personality traits $[\lambda=0.78 ; F(10.198)=2.52 ; p<$ $\left..05 ; \eta^{2}=0.11\right]$. The results showed a significant difference on extraversion $\left[F(2.103)=3.65 ; p<.05 ; \eta^{2}\right.$ $=0.06]$ and kindness traits $\left[F(2.103)=8.03 ; p<.05 ; \eta^{2}=0.14\right]$. The investigation suggests that among these subjects, different personality traits may influence preference for certain periods of the day to carry out daily activities and that there is a relationship with the standard chronotype. Also, the results indicate that men and women have different personality traits when the effects of the sleep behavior are checked.
\end{abstract}

Keywords: Chronotype, sleep, personality traits.

\section{Traços de Personalidade e Padrões Comportamentais do Sono: Diferenças entre Homens e Mulheres}

\section{Resumo}

O presente estudo teve o objetivo de verificar os efeitos comportamentais do sono nos traços de personalidade de adultos jovens. Participaram desta pesquisa 114 voluntários entre 18 e 40 anos de idade. Os sujeitos foram divididos em três grupos: Moderadamente Matutino $(n=23)$; Intermediário

* Mailing address: Cidade Universitária, Centro de Ciências Humanas, Letras e Artes, Departamento de Pósgraduação em Psicologia Social, João Pessoa, PB, Brazil 58051-900. Phone: 55 (83) 3216-7200, 55 (83) 32167064. E-mail: m.jackson_20@yahoo.com.br, victorhdiaspereira@gmail.com, lhenrique_melo@hotmail.com, natanael_labv@yahoo.com.br and melyssa_cavalcanti@hotmail.com

Financiamento: Universidade Federal da Paraíba. 
$(n=52)$ e Moderadamente Vespertino $(n=39)$. Entre os instrumentos de pesquisa utilizou-se o Questionário de Matutinidade e Vespertinidade de Horne e Östberg e Inventário dos Cinco Grandes Fatores de Personalidade. A MANOVA mostrou diferença significativa entre os cronotipos e os traços de personalidade $\left[\lambda=0,78 ; F(10,198)=2,52 ; p<0,05 ; \eta^{2}=0,11\right]$. Observou-se diferença significativa apenas para os traços de extroversão $\left[F(2,103)=3,65 ; p<0,05 ; \eta^{2}=0,06\right]$ e amabilidade $[F(2,103)$ $\left.=8,03 ; p<0,05 ; \eta^{2}=0,14\right]$. Este estudo sugere que pessoas com diferentes traços de personalidades possuem horas específicas para realizar suas atividades e que existe uma relação com o padrão do cronotipo. Em geral, os dados indicam que homens e mulheres apresentam traços de personalidade diferentes em relação aos efeitos comportamentais do sono.

Palavras-chave: Cronotipo, sono, traços de personalidade.

\section{Rasgos de Personalidad y lós Patrones de Sueño de Comportamiento: Diferencias entre Hombres y Mujeres}

\section{Resumen}

Este estúdio tuvo como objetivo verificar los efectos del comportamento del sueño em los rasgos de personalidad de los adultos jóvenes. El estúdio recogió 114 voluntarios de entre 18 y 40 años de edad. Los sujetos fueron divididos entres grupos: Moderadamente mañana $(n=23)$; Intermedio $(n=52)$ y moderadamente Vespertino $(n=39)$. Entre el instrumento de estudio utilizado el Cuestionario matutinidad y vespertinidad Horne y Östberg y el Inventario de los cinco grandes factores. MANOVA mostró una diferencia significativa entre el cronotipo y rasgos de personalidad $[\lambda=0.78 ; F(10.198)=2.52 ; p<.05$; $\left.\eta^{2}=0.11\right]$. Los resultados mostraron una diferencia significativa en la extraversión $[F(2.103)=3.65 ; p$ $\left.<.05 ; \eta^{2}=0.06\right]$ y rasgos de bondad $\left[F(2.103)=8.03 ; p<.05 ; \eta^{2}=0.14\right]$. La investigación sugiere que entre estos sujetos, diferentes rasgos de personalidad pueden influir en la preferencia por ciertos períodos del día para llevar a cabo las actividades diarias y que existe una relación con el cronotipo estándar. Además, los resultados indican que hombres y mujeres tienen diferentes rasgos de personalidad cuando se comprueban los efectos del comportamiento del sueño.

Palabras clave: Cronotipo, sueño, rasgos de personalidade.

Chronobiology has the function to study the variation of biological rhythms. It is possible to show that multiple processes in the brain have a regular pattern with rhythm of approximately 24 hours (Blatter \& Cajochen, 2007; Marques \& Menna-Barreto, 1997). Human beings receive external influences periodically along the day with the function to organize information in the central nervous system (Valdez, Ramírez, \& Garcia, 2012). Intrinsic to these rhythmic patterns, the cognitive processes and behavioral functions admit temporal functions synchronized between the internal and external organism environment (Blatter \& Cajochen, 2007). For example, sleep, a behavioral state well-defined in architectures of electroencephalographic phases, plays a fundamental role for neurocognitive synchronization (Besílio, Mutton, Silva, Strong, \&, 2012).
The circadian typology or standard of chronotype has been associated with cognitive and behavioral function of psychological processes, as for example, attentional and mnemonic measures, decision-making and social perception (Tankova, Adan, \& Buela-Casal, 1994). In general, morning people (i.e. who have preference to carry out activities in the morning period and evening people), who have preference to perform activities in the night shift, associate levels of cerebral excitement according to personality traits profiles. In particular, inter-individual rhythmic variations between rhythmic show specific domains of personality traits with morning or evening preference (Albany Adult, Hasher, Djikic, Criger, \& Peterson, 2007; Larsen, 1985; Mecacci, Zani, Rocchetti, \& Lucioli, 1986; Mitchell \& Redman, 1993; Neubauer, 
1992; Tonetti et al., 2010; Torsvall \& Åkerstedt, 1980).

Various studies show that evening subjects tend to have a higher propensity for traits of extroversion, mainly when the personality trait is associated with sociability patterns (Larsen, 1985; Mecacci et al., 1986; Randler, Baumann, \& Horzum, 2014). DeYoung et al. (2007) and Tonetti et al. (2010) showed that in addition to extroversion, evening subjects may present behaviors that are characteristic of neuroticism and psychoticism, being less dependent than morning subjects. On the other hand, the morning subjects tend to be more introverted and present greater involvement in sociocultural values (Russian, Leone, Penolazzi, \& Natale, 2012).

On the other hand, Neubauer's study (1992) suggests that extroversion, also associated with the component of impulsivity, is correlated positively to morningness patterns. Furthermore, the research indicated an intrinsic association between neuroticism and eveningness. These findings suggest an association between personality trait with a chronotype pattern. Whereas Horne and Östberg (1975) showed that subjects with high scores on the extroversion trait tend to carry out their activities in the night period while subjects with high scores in introversion demonstrate preferences for activities in the morning period. In spite of studies exhibiting data correlation adult subjects, the researchers are still contradictory and do not display conclusive results.

Randler (2007) sought to associate the chronotype with the personality traits using the hierarchical model of the Big Five Personality Factors. According to John and Srivastava (1999), this model is derived from the analysis of the language terms that subjects use in their natural environments to describe themselves and others. The validation of this scale in Brazil presents five categories of personality: openness, conscientiousness, extroversion, agreeableness and neuroticism (Andrade, 2008). Randler (2007) points out that morning men and women correlated to each other positively with traits of agreeableness, conscientiousness and socialization, corroborating the results of Jackson and Gerard (1996). Still, Randler and Saliger (2011) showed that morning adolescents presented higher scores in temperaments of persistence and cooperation, while evening adolescents have higher scores in search for news and are prone to dependency by reward. Overall, the researchers attributed those results to an excitatory function of neurotransmitters in circadian time, but they do not explain how these neural mechanisms adjust for the presence and absence of light (main circadian synchronizer).

According to Roenneberg et al. (2004) factors such as age and gender may influence the construction of the sleep architecture and personality. For example, the delay in the start of the sleep phase if different between men and women. For men it happens around 21 years old whereas in women the behavior takes place two years earlier (i.e., at 19 years old. Age presents a biological functionality distinct for both sexes and provides a maturation in preference for chronotype; Díaz-Morales, de León, \& Sorroche, 2007; Randler, 2007). Still, the difference in speed of pubertal development between boys and girls is a determinant factor in the changes that occur in the circadian rhythms (Díaz-Morales et al., 2007). Thus, sleep aspects can be associated to perceptions of health, energy levels, welfare, functional status and measures of personality traits in men and women (Duggan, Friedman, McDevitt, \& Mednick, 2014). The study herein starts from the hypothesis that influences and social life experiences of young adults differ regarding their chronotype, that is, the formation of personality traits of men and women is different according to their morningness and eveningness standard (Randler, 2007).

As the relationship between the sleep-wake cycle and the sleep quality levels can modify the cognitive and behavioral functioning of the subjects, influencing indirectly the personality traits (Randler et al., 2014). The differences found in the personality traits associated with the chronotype propose Chrono psychological perspectives aiming at a construction of a theoretical model that explains causes and typological circadian manifestations related to the personality traits.

Even though a significant number of studies quantify the relationship between chronotype 
and personality traits, there is a large quantity of inconclusive and misinterpreted results, as well as gaps in the investigation of the effects of the sleep behavior in men's and women's personalities traits. The study herein had as its main objective to verify the sleep behavioral effects in young adult's men's and women's personality traits.

\section{Method}

\section{Subjects}

One hundred and fourteen volunteers aged between 18 and 40 years old participated in this research. The subjects were divided into three groups according to the chronotype pattern (Table 1 ). Initially 45 survey participants were withdrawn from the research for presenting light anxiety rates $(75.5 \%)$ and moderate depression $(25.5 \%)$. All volunteers were university students and were clinically stable, not presenting identifiable neuropsychiatric disorders, being free from any disorder that affected their sleep. Any participant who made use of some type of drug that affected the central nervous system or toxic substances was excluded from the study.

Table 1

Sample Data by Sleep Behavior Standard or Chronotype

\begin{tabular}{lcccc}
\hline \multirow{2}{*}{ Chronotype } & \multicolumn{3}{c}{ Man } & \multicolumn{3}{c}{ Woman } \\
\cline { 2 - 5 } & $n$ & Age & $n$ & Age \\
\hline Moderately morning & 7 & $24.86(6.9)$ & 16 & $22.06(3.4)$ \\
Intermediate & 13 & $22.23(3.6)$ & 39 & $20.72(3.6)$ \\
Moderately Evening & 13 & $24.69(3.1)$ & 26 & $21.12(3.9)$ \\
\multicolumn{1}{r}{ Total } & 33 & $23.93(4.5)$ & 78 & $21.3(3.6)$ \\
\hline
\end{tabular}

\section{Instruments}

Sociodemographic Questionnaire. This questionnaire is composed of social issues (such as sex, age, time preference, monthly income, among others) and clinical (physical activity, psychological and neurological impairments, consumption of psychoactive substances, among others) in accordance with the needs of the study.

Morningness and Eveningness Questionnaire by Horne and Östberg. Prepared by Horne and Östberg (1975) and adapted/validated to Portuguese Language by Benedito-Silva, Menna-Barreto, Marques and Tenreiro (1990). The instrument is intended to evaluate the preference of the subject in performing his or her activities during the period of 24 hours. Comprising 19 questions about usual situations of daily life of the subject and their respective scores, they classify subjects into five categories according to the chronotype: evening (16 to 30 points); moderately evening (31 to 41 points); indifferent or intermediary (42 to 58 points); moderately morning (59 to 69 points); and morning (70 to 86 points).

Pittsburgh Sleep Quality Index (PSQI). The instrument consists of 19 questions and it is divided into seven subjective components about sleep compared to the one month ago: 1) sleep quality; 2) sleep latency; 3) sleep duration; 4) sleep efficiency; 5) Sleep disturbances; 6) use of sleeping medication; 7) daytime sleepiness and disturbances throughout the day. Each component has alternatives with scores that vary between zero and 3 points, where zero indicates none and 3 points to a serious problem (i.e., poor sleep quality). The total sum of points varies from 0 to 21 points (Furlani \& Ceolim, 2005). It should be emphasized that its validation in Portuguese language was performed with a high degree of sensitivity (65\%). 
Sleep Dairy. This instrument was developed by the laboratory itself and its completion aimed to describe the sleep behavior patterns during a period of 14 consecutive days according to the items: sleep latency, sleep efficiency, the form of waking up and schedules and duration of naps.

Inventory of the Big Five Personality Factors (IGFP-5). The IGPF-5 has 44 items, structured in a Likert scale ranging from strongly disagree completely (1) until completely agree (5). The items are grouped into five factors: Opening, conscientiousness, extroversion, agreeableness and neuroticism. Its validation for the Brazilian population was performed by Andrade (2008) in a sample of 5,089 subjects aged from 13 to 67 years old.

Beck Anxiety Inventory (BAI). It has 21 items and evaluates the intensity the Clinic Anxiety Clinic intensity $(\alpha=0.92)$. According to Cunha (1999), the Interpretation of the anxiety levels can be seen as follows: minimum limit (0-10 points); mild anxiety (11-19 points); moderate anxiety (20-30 points); and severe anxiety (31-63 points).

The Beck Depression Inventory (BDI). This inventory consists of 21 categories of symptoms and attitudes that describe behavioral, cognitive, affective and somatic depression manifestations (Cunha, 1999). Each category contains from four to five alternatives that express severity levels of depressive symptoms. The score for each category varies from 0 to 3 , being the smallest value the absence of depressive symptoms and the greatest value the presence of more intense symptoms. The interpretation of the results is subdivided into: absence of depression (up to 9 points); mild to moderate depression (10-18 points); moderate to severe depression (19-29); and severe depression (30-63 points).

Visual Analogue Scale for Attention. Designed to assess aspects of subjective experiences related to fatigue, tension, attention and state of alertness of the participant during a period of 24 hours. The participant is shown to indicate on a scale from zero to 20 how he or she feels in this moment regarding to each of the subjective experiences indicated. In this scale zero corresponds to Nothing and 20 to A lot (Laneiro,
Brites, Tap, Silva, Reguinga, \& War, 2011).

Procedure

The present study was conducted at the Federal University of Paraíba. It was initially performed the contact with participants to explain about ethical issues and procedures to be carried out in the research, this step was done in class with the Professors' informed consent. At that time, to the participants the questionnaires on sampling survey were presented (Socio-demographic Morningness-eveningness Questionnaire by Horne \& Östberg, Inventory of the Big Five personality factors [IGFP-5], Pittsburgh Sleep Quality Index [PSQI], Beck Anxiety Inventory [BAI], and Beck Depression Inventory, $\mathrm{BDI})$. According to the explanations, the participants answered the questionnaires individually. All the instruments were self-report.

After answering the sampling survey questionnaires, the participants received the Visual Analogue Scale for attention and the Sleep Diary. All of them were instructed to respond the scales for a period of 14 consecutive days, beginning always on a Friday (day when the protocols were handed out), in order to understand a behavior pattern in business and non-business days of the week. The four dimensions of Visual Analogue Scale for attention were answered on a daily basis during the hours 9:00 am, 03:00 $\mathrm{pm}$ and 9:00 pm. Likewise, the sleep diary was completed daily with content about social daily and night habits. It was recommended the participants to remain regular in their daily responses and that they were made mainly in the in the night period.

After handing out the material, the participants> responses were plotted in spreadsheets according to the chronotype and the variables of interest, being carried out Descriptive and Inferential statistical analyzes by means of SPSS (Statistical Package for the Social Sciences), version 20 . The data descriptive analyzes were verified by means of frequency and measures of central tendency. The multivariate normality conditions of the data were checked prior to the application of the inferential statistical tests within the $95 \%$ confidence interval (Ko- 
mogorov-Sminorv). Multivariate analysis of variance (MANOVA one way) was used with Statistics of Lambda Wilks to evaluate the hypothesis of the study. Consequently, it was verified the multiple comparisons of factors through ANOVA. Once identified the significance between the ANOVA tests post-hoc Tukey and Bonferroni test were carried out to check the means multiple comparisons.

\section{Ethical Aspects}

The study was submitted to the unified basis of records of research involving human being (Platforma Brasil) and approved by the Ethics Committee of the Health Sciences Center (SCC) of the public institution affiliated under the protocol.32183114.7.0000.5183. Participation in the survey was voluntary, being guaranteed the anonymity and confidentiality of the information by signing the Informed Consent Form (ICF), following the precepts of Resolution no. 466/12 from the National Health Council.

\section{Results}

\section{General Aspects}

Initially, no significant difference was observed between the ages and the level of sleep quality among participants according to the chronotype $(p>.01)$. Most of participants were female (77\%) and out of these $48 \%$ had intermediary chronotype. The analysis also showed that there was no difference between the groups in relation to the consumption of drugs like coffee and alcohol $(p>.01)$. All the participants were free from diseases related to sleep, but $5 \%$ had some third degree relative with some neuro-psychiatric disorder.

\section{Sleep Behavioral Dimensions}

The analysis of variance (ANOVA one way) showed a significant difference during sleep time and waking up among the chronotypes (Table 2). The data showed that during the week days the subjects had differences for sleep time $[F(2.100)$ $=3.20 ; p<.05]$ and wake up time $[F(2.100)=$ $9.41 ; p<.05]$. The post hoc Tukey test showed that the ME subjects seek to sleep later and wake up later than the MM subjects $(p<.05)$. These sleep behavior patterns remained during the weekends for both the sleep time [F $(2.106)=$ $2.72 ; p<.05]$ and the wake up time $[F(2.104)=$ $27.75 ; p<.05]$. Again, the ME subjects went to sleep later that the I and MM subjects $(p<.05)$. Besides, the intermediary subjects went to sleep later that the MM subjects $(p<.05)$. These measures were repeated among the subjects in relation to the wake up time $(p<.05)$. There were no differences in latencies between the minutes for time to wake up and sleep between the groups, regardless of the days of the week.

Table 2

Sleep Behavioral Patterns according to the Sleep Dairy on Week Days and Weekends

\begin{tabular}{|c|c|c|c|c|c|c|}
\hline \multirow{2}{*}{ Sleep dairy } & \multicolumn{2}{|c|}{ moderately morning } & \multicolumn{2}{|c|}{ Intermediate } & \multicolumn{2}{|c|}{ Moderately Evening } \\
\hline & $M$ & $S D$ & $M$ & $S D$ & $M$ & $S D$ \\
\hline \multicolumn{7}{|l|}{ Week } \\
\hline Sleep time & 00:39 & \pm 178 & 11:50 PM & \pm 94 & 11:11 PM & \pm 85 \\
\hline Sleep latency & 12 & \pm 17 & 11 & \pm 11 & 15 & \pm 18 \\
\hline Wake up Time & 7:48 AM & \pm 113 & 7:09 AM & \pm 105 & 7:48 AM & \pm 113 \\
\hline Latency to wake up & 12 & \pm 17 & 11 & \pm 11 & 15 & \pm 18 \\
\hline \multicolumn{7}{|l|}{ Weekend } \\
\hline Sleep time & $1: 20 \mathrm{AM}$ & \pm 131 & 12:18 AM & \pm 88 & $11: 44$ PM & \pm 111 \\
\hline Sleep latency & 20 & \pm 24 & 14 & \pm 16 & 18 & \pm 18 \\
\hline Wake up time & 9:40 AM & \pm 111 & 8:19 AM & \pm 92 & 9:40 AM & \pm 111 \\
\hline Latency to wake up & 20 & \pm 24 & 14 & \pm 16 & 18 & \pm 18 \\
\hline
\end{tabular}


The results also showed significant differences among the chronotypes and the dimensions of the visual analog scale in accordance with the dimensions assessed (Table 3). For dimension fatigue: there was a difference in the period of 09 $\operatorname{pm}[F(2.39)=3.28 ; p<.05]$ being that the subjects I showed higher fatigue than the MM $(p<$ $.05)$. In relation to the attention and state of alertness dimensions' data showed that: the subjects showed significant differences at the time of 03 $\mathrm{pm}$ for both attention $[F(2.39)=4.63 ; p<.05]$ and for the state of alertness $[F(2.39)=7.37 ; p<$ $.05]$. In general, ME participants showed higher levels of attention and state of alertness than the MM subjects $(p<.05)$, in addition to higher levels of alertness than the I subjects $(p<.05)$. The data showed no significant difference in the dimension sleepiness.

Table 3

Scores of Visual Analogue Scale according to the Chronotype and Measurement Time

\begin{tabular}{|c|c|c|c|c|c|c|c|c|c|}
\hline \multirow{2}{*}{$\begin{array}{c}\text { Visual Analogue } \\
\text { Scale }\end{array}$} & \multicolumn{3}{|c|}{ moderately morning } & \multicolumn{3}{|c|}{ Intermediate } & \multicolumn{3}{|c|}{ Moderately Evening } \\
\hline & $\begin{array}{l}\text { 09:00 } \\
\text { am }\end{array}$ & $\begin{array}{l}\text { 03:00 } \\
\text { pm }\end{array}$ & $\begin{array}{l}\text { 09:00 } \\
\text { pm }\end{array}$ & $\begin{array}{l}\text { 09:00 } \\
\text { am }\end{array}$ & $\begin{array}{c}\text { 03:00 } \\
\mathrm{pm}\end{array}$ & $\begin{array}{c}\text { 09:00 } \\
\text { pm }\end{array}$ & $\begin{array}{l}\text { 09:00 } \\
\text { am }\end{array}$ & $\begin{array}{l}\text { 03:00 } \\
\mathrm{pm}\end{array}$ & $\begin{array}{c}\text { 09:00 } \\
\mathrm{pm}\end{array}$ \\
\hline \multicolumn{10}{|l|}{ Week } \\
\hline Fatigue & $\begin{array}{l}5.51 \\
(5.1)\end{array}$ & $\begin{array}{l}7.57 \\
(5.5)\end{array}$ & $\begin{array}{l}10.46 \\
(6.0)\end{array}$ & $\begin{array}{l}7.37 \\
(5.2)\end{array}$ & $\begin{array}{l}8.28 \\
(4.7)\end{array}$ & $\begin{array}{l}9.98 \\
(5.3)\end{array}$ & $\begin{array}{l}10.34 \\
(5.7)\end{array}$ & $\begin{array}{l}8.92 \\
(5.8)\end{array}$ & $\begin{array}{l}8.82 \\
(5.8)\end{array}$ \\
\hline Sleepiness & $\begin{array}{l}5.57 \\
(4.9)\end{array}$ & $\begin{array}{l}7.29 \\
(5.4)\end{array}$ & $\begin{array}{l}11.32 \\
(6.5)\end{array}$ & $\begin{array}{l}8.35 \\
(5.4)\end{array}$ & $\begin{array}{l}8.72 \\
(4.9)\end{array}$ & $\begin{array}{l}10.34 \\
(5.1)\end{array}$ & $\begin{array}{l}12.02 \\
(5.2)\end{array}$ & $\begin{array}{l}9.97 \\
(5.6)\end{array}$ & $\begin{array}{l}9.80 \\
(5.7)\end{array}$ \\
\hline Attention & $\begin{array}{l}12.09 \\
(5.7)\end{array}$ & $\begin{array}{l}11.29 \\
(5.3)\end{array}$ & $\begin{array}{l}9.70 \\
(5.7)\end{array}$ & $\begin{array}{l}10.69 \\
(4.9)\end{array}$ & $\begin{array}{l}11.55 \\
(4.1)\end{array}$ & $\begin{array}{l}10.91 \\
(4.4)\end{array}$ & $\begin{array}{l}9.35 \\
(5.0)\end{array}$ & $\begin{array}{l}11.74 \\
(4.7)\end{array}$ & $\begin{array}{l}12.05 \\
(4.5)\end{array}$ \\
\hline State of Alertness & $\begin{array}{l}9.43 \\
(5.1)\end{array}$ & $\begin{array}{l}11.62 \\
(4.9)\end{array}$ & $\begin{array}{l}12.22 \\
(4.5)\end{array}$ & $\begin{array}{l}10.68 \\
(5.2)\end{array}$ & $\begin{array}{l}11.50 \\
(4.8)\end{array}$ & $\begin{array}{l}10.72 \\
(4.6)\end{array}$ & $\begin{array}{l}9.43 \\
(5.1)\end{array}$ & $\begin{array}{l}11.62 \\
(4.9)\end{array}$ & $\begin{array}{l}12.22 \\
(4.5)\end{array}$ \\
\hline \multicolumn{10}{|l|}{ Weekend } \\
\hline Fatigue & $\begin{array}{l}6.11 \\
(5.8)\end{array}$ & $\begin{array}{l}7.43 \\
(5.7)\end{array}$ & $\begin{array}{l}10.07 \\
(6.1)\end{array}$ & $\begin{array}{l}8.06 \\
(6.1)\end{array}$ & $\begin{array}{l}7.68 \\
(5.0)\end{array}$ & $\begin{array}{l}9.01 \\
(4.6)\end{array}$ & $\begin{array}{l}11.68 \\
(6.6)\end{array}$ & $\begin{array}{l}7.06 \\
(5.3)\end{array}$ & $\begin{array}{l}7.41 \\
(5.5)\end{array}$ \\
\hline Sleepiness & $\begin{array}{l}7.39 \\
(6.3)\end{array}$ & $\begin{array}{l}8.10 \\
(5.8)\end{array}$ & $\begin{array}{l}10.24 \\
(6.2)\end{array}$ & $\begin{array}{l}9.59 \\
(6.1)\end{array}$ & $\begin{array}{l}8.36 \\
(5.3)\end{array}$ & $\begin{array}{l}8.85 \\
(4.5)\end{array}$ & $\begin{array}{l}12.74 \\
(6.4)\end{array}$ & $\begin{array}{l}8.06 \\
(5.7)\end{array}$ & $\begin{array}{l}7.65 \\
(5.0)\end{array}$ \\
\hline Attention & $\begin{array}{l}10.37 \\
(6.6)\end{array}$ & $\begin{array}{l}11.24 \\
(4.7)\end{array}$ & $\begin{array}{l}10.02 \\
(5.5)\end{array}$ & $\begin{array}{l}9.69 \\
(5.3)\end{array}$ & $\begin{array}{l}11.29 \\
(4.3)\end{array}$ & $\begin{array}{l}11.41 \\
(3.9)\end{array}$ & $\begin{array}{l}6.62 \\
(5.5)\end{array}$ & $\begin{array}{l}13.03 \\
(4.5)\end{array}$ & $\begin{array}{c}12.74 \\
(4.4)\end{array}$ \\
\hline State of Alertness & $\begin{array}{l}6.44 \\
(5.7)\end{array}$ & $\begin{array}{c}12.78 \\
(5.0)\end{array}$ & $\begin{array}{l}12.92 \\
(4.6)\end{array}$ & $\begin{array}{l}9.24 \\
(5.3)\end{array}$ & $\begin{array}{l}11.38 \\
(4.5)\end{array}$ & $\begin{array}{l}11.25 \\
(4.4)\end{array}$ & $\begin{array}{l}6.44 \\
(5.7)\end{array}$ & $\begin{array}{c}12.78 \\
(4.9)\end{array}$ & $\begin{array}{c}12.92 \\
(4.6)\end{array}$ \\
\hline
\end{tabular}

In relation to the participants' sex and the chronotype pattern the two-way ANOVA showed the following results. There was a difference during the business and non-business days of the week so that women had significant differences for the wake up time $[F(2.73)=19.86, p<$ $.05]$ and for sleep time $[F(2.74)=9.06 ; p<.05]$ on weekends and also for wake up time during the business days $[F(2.72)=7.46 ; p<.05]$. The data showed that ME women sleep and wake up later than I and MM women $(p<.05)$. Regarding the male sex, the data indicated that there is no significant difference for sleep time $[F(2.29)=$ $3.34 ; p<.05]$ and wake up time $[F(2.28)=7.31$; $p<.05]$ only during the weekends. The scores of the subjects' sleep diary can be observed in the Table 4. 
Table 4

Sleep Behavioral Patterns according to the Sleep Dairy for Men and Women on Week Days and Weekends

\begin{tabular}{|c|c|c|c|c|c|c|}
\hline \multirow[b]{2}{*}{ Women } & \multicolumn{4}{|c|}{ Sleep dairy } & & \\
\hline & \multicolumn{2}{|c|}{ moderately morning } & \multicolumn{2}{|c|}{ Intermediate } & \multicolumn{2}{|c|}{ Moderately Evening } \\
\hline Week & Mean & $S D$ & Mean & $S D$ & Mean & $S D$ \\
\hline Sleep time & 11:11 PM & \pm 82 & 11:40 PM & \pm 89 & $12: 36 \mathrm{AM}$ & \pm 114 \\
\hline Sleep latency & 10 & \pm 10 & 12 & \pm 19 & 12 & \pm 16 \\
\hline Wake up Time & $6: 27 \mathrm{AM}$ & \pm 97 & $6: 58 \mathrm{AM}$ & \pm 105 & 7:49 AM & \pm 111 \\
\hline Latency to wake up & 13 & \pm 18 & 11 & 12 & 13 & \pm 18 \\
\hline \multicolumn{7}{|l|}{ Weekend } \\
\hline Sleep time & 11:46 PM & \pm 120 & $12: 21 \mathrm{AM}$ & \pm 88 & $1: 28 \mathrm{AM}$ & \pm 119 \\
\hline Sleep latency & 9 & \pm 8 & 13 & \pm 18 & 13 & \pm 19 \\
\hline Wake up Time & 7:29 AM & \pm 112 & 8:19 AM & \pm 91 & $9: 40 \mathrm{AM}$ & \pm 101 \\
\hline Latency to wake up & 17 & \pm 15 & 16 & \pm 19 & 17 & \pm 15 \\
\hline Men & \multicolumn{2}{|c|}{ moderately morning } & \multicolumn{2}{|c|}{ Intermediate } & \multicolumn{2}{|c|}{ Moderately Evening } \\
\hline Week & Mean & $S D$ & Mean & $S D$ & Mean & $S D$ \\
\hline Sleep time & $11: 21 \mathrm{PM}$ & \pm 75 & 12:10 AM & \pm 69 & 1:00 AM & \pm 150 \\
\hline Sleep latency & 13 & \pm 11 & 13 & \pm 10 & 18 & \pm 15 \\
\hline Wake up Time & $6: 26 \mathrm{AM}$ & \pm 52 & $7: 40 \mathrm{AM}$ & \pm 95 & 7:58 AM & \pm 117 \\
\hline Latency to wake up & 13 & \pm 14 & 10 & \pm 8 & 16 & \pm 16 \\
\hline \multicolumn{7}{|l|}{ Weekend } \\
\hline Sleep time & 11:50 PM & \pm 89 & $12: 20 \mathrm{AM}$ & \pm 75 & $1: 37 \mathrm{AM}$ & \pm 135 \\
\hline Sleep latency & 13 & \pm 14 & 11 & \pm 8 & 28 & \pm 40 \\
\hline Wake up Time & 7:33 AM & \pm 83 & 8:18 AM & \pm 97 & 9:38 AM & \pm 135 \\
\hline Latency to wake up & 26 & \pm 30 & 11 & \pm 7 & 19 & \pm 17 \\
\hline
\end{tabular}

The results also showed significant differences among the women's and men's chronotypes and the dimensions of the visual analogue scale (Table 5). The data show that women exhibited differences in the period from $9 \mathrm{pm}$ to the dimension fatigue $[F(2.39)=3.26 ; p<$ $.05]$ and at $03 \mathrm{pm}$ to the dimensions attention $[F(2.39)=5.94 ; p<.05 ;$ and state of alertness $[F(2.39)=8.58 ; p<.05]$. The post hoc Turkey analysis showed that MM women have a higher fatigue than women with I $(p<.05)$. In addition, ME women have higher levels of attention and state of alertness at $03 \mathrm{pm}$ when compared with MM women $(p<.05)$. The analysis among men showed significant difference only for the dimension state of alertness $[F(2.39)=5.51 ; p$ $<.05$ ], where the I subjects had higher scores of alertness that the ME subjects $(p<.05)$. In general, women suffer greater variation in their behavioral dimensions when compared to men $(p<.01)$. 
Table 5

Scores of Visual Analogue Scale according to the Chronotype of Men and Women and Measurement Time

\begin{tabular}{lccccccccc}
\hline \multirow{2}{*}{ Women } & \multicolumn{2}{c}{ Moderately Morning } & \multicolumn{3}{c}{ Intermediate } & \multicolumn{3}{c}{ Moderately Evening } \\
\cline { 2 - 9 } Week & $\begin{array}{c}09: 00 \\
\mathrm{am}\end{array}$ & $\begin{array}{c}03: 00 \\
\mathrm{pm}\end{array}$ & $\begin{array}{c}09: 00 \\
\mathrm{pm}\end{array}$ & $\begin{array}{c}09: 00 \\
\mathrm{am}\end{array}$ & $\begin{array}{c}103: 00 \\
\mathrm{pm}\end{array}$ & $\begin{array}{c}09: 00 \\
\mathrm{pm}\end{array}$ & $\begin{array}{c}09: 00 \\
\mathrm{am}\end{array}$ & $\begin{array}{c}03: 00 \\
\mathrm{pm}\end{array}$ & $\begin{array}{c}09: 00 \\
\mathrm{pm}\end{array}$ \\
\hline \multirow{2}{*}{ Fatigue } & 5.78 & 7.87 & 10.81 & 7.07 & 8.57 & 10.67 & 10.14 & 8.64 & 8.58 \\
& $(5.2)$ & $(5.4)$ & $(5.9)$ & $(5.3)$ & $(4.7)$ & $(5.3)$ & $(5.8)$ & $(5.6)$ & $(5.9)$ \\
Sleepiness & 6.19 & 7.22 & 10.91 & 8.11 & 8.93 & 10.71 & 11.62 & 10.14 & 9.28 \\
& $(5.2)$ & $(5.3)$ & $(6.0)$ & $(5.4)$ & $(4.9)$ & $(5.1)$ & $(5.2)$ & $(5.5)$ & $(5.7)$ \\
Attention & 11.94 & 11.32 & 9.34 & 10.90 & 11.40 & 10.53 & 9.14 & 11.5 & 12.12 \\
& $(5.5)$ & $(5.2)$ & $(5.6)$ & $(4.9)$ & $(4.4)$ & $(4.5)$ & $(5.0)$ & $(4.6)$ & $(4.5)$ \\
State of Alertness & 10.50 & 10.25 & 7.94 & 10.89 & 11.53 & 10.34 & 9.39 & 11.61 & 12.10 \\
Weekend & $(6.2)$ & $(6.6)$ & $(5.9)$ & $(5.3)$ & $(4.9)$ & $(4.9)$ & $(4.9)$ & $(4.5)$ & $(4.7)$ \\
\multirow{4}{*}{ Fatigue } & & & & & & & & & \\
& & & & & & & & & \\
Sleepiness & 7.03 & 7.81 & 10.44 & 7.49 & 7.40 & 9.19 & 10.67 & 7.44 & 7.60 \\
& $(5.9)$ & $(6.5)$ & $(6.4)$ & $(6.1)$ & $(4.9)$ & $(4.3)$ & $(6.6)$ & $(5.3)$ & $(5.5)$ \\
Attention & $(6.81$ & 8.20 & 10.22 & 9.31 & 8.46 & 8.78 & 12.15 & 7.50 & 7.34 \\
& $(6.3)$ & $(6.3)$ & $(6.6)$ & $(6.2)$ & $(5.4)$ & $(4.4)$ & $(6.5)$ & $(5.9)$ & $(5.1)$ \\
State of Alertness & 9.60 & 10.88 & 9.19 & 9.58 & 11.35 & 11.14 & 6.84 & 12.34 & 12.12 \\
& $(6.9)$ & $(4.8)$ & $(5.7)$ & $(5.3)$ & $(4.5)$ & $(3.8)$ & $(5.6)$ & $(4.6)$ & $(4.5)$ \\
& 9.38 & 9.88 & 8.03 & 9.05 & 11.51 & 11.00 & 6.67 & 12.58 & 12.84 \\
& $(6.6)$ & $(5.8)$ & $(6.2)$ & $(5.3)$ & $(4.6)$ & $(4.4)$ & $(5.7)$ & $(4.9)$ & $(4.5)$
\end{tabular}

\begin{tabular}{|c|c|c|c|c|c|c|c|c|c|}
\hline \multirow{2}{*}{$\begin{array}{l}\text { Men } \\
\text { Week }\end{array}$} & \multicolumn{3}{|c|}{ Moderately Morning } & \multicolumn{3}{|c|}{ Intermediate } & \multicolumn{3}{|c|}{ Moderately Evening } \\
\hline & $\begin{array}{c}\text { 09:00 } \\
\text { am }\end{array}$ & $\begin{array}{c}\text { 03:00 } \\
\text { pm }\end{array}$ & $\begin{array}{c}\text { 09:00 } \\
\text { pm }\end{array}$ & $\begin{array}{c}\text { 09:00 } \\
\text { am }\end{array}$ & $\begin{array}{c}\text { 03:00 } \\
\text { pm }\end{array}$ & $\begin{array}{c}\text { 09:00 } \\
\text { pm }\end{array}$ & $\begin{array}{c}\text { 09:00 } \\
\text { am }\end{array}$ & $\begin{array}{c}\text { 03:00 } \\
\text { pm }\end{array}$ & $\begin{array}{c}09: 00 \\
\mathrm{pm}\end{array}$ \\
\hline Fatigue & $\begin{array}{l}3.36 \\
(3.3)\end{array}$ & $\begin{array}{l}6.69 \\
(4.4)\end{array}$ & $\begin{array}{l}10.01 \\
(5.3)\end{array}$ & $\begin{array}{l}8.09 \\
(5.3)\end{array}$ & $\begin{array}{l}7.60 \\
(4.5)\end{array}$ & $\begin{array}{l}8.42 \\
(5.2)\end{array}$ & $\begin{array}{c}10.75 \\
(5.6)\end{array}$ & $\begin{array}{l}9.76 \\
(6.1)\end{array}$ & $\begin{array}{l}8.83 \\
(5.6)\end{array}$ \\
\hline Sleepiness & $\begin{array}{l}4.07 \\
(3.5)\end{array}$ & $\begin{array}{l}7.49 \\
(5.2)\end{array}$ & $\begin{array}{l}11.50 \\
(6.7)\end{array}$ & $\begin{array}{l}8.33 \\
(5.3)\end{array}$ & $\begin{array}{l}8.15 \\
(4.9)\end{array}$ & $\begin{array}{l}8.81 \\
(5.0)\end{array}$ & $\begin{array}{c}12.31 \\
(5.6)\end{array}$ & $\begin{array}{c}10.56 \\
(5.9)\end{array}$ & $\begin{array}{c}10.04 \\
(5.9)\end{array}$ \\
\hline Attention & $\begin{array}{l}12.29 \\
(6.1)\end{array}$ & $\begin{array}{l}11.07 \\
(5.2)\end{array}$ & $\begin{array}{l}10.86 \\
(5.8)\end{array}$ & $\begin{array}{c}10.39 \\
(4.8)\end{array}$ & $\begin{array}{l}11.62 \\
(3.6)\end{array}$ & $\begin{array}{l}11.89 \\
(4.5)\end{array}$ & $\begin{array}{l}9.80 \\
(5.3)\end{array}$ & $\begin{array}{c}12.23 \\
(5.1)\end{array}$ & $\begin{array}{c}12.64 \\
(3.7)\end{array}$ \\
\hline State of Alertness & $\begin{array}{l}11.07 \\
(6.8)\end{array}$ & $\begin{array}{l}11.00 \\
(5.5)\end{array}$ & $\begin{array}{l}11.40 \\
(6.1)\end{array}$ & $\begin{array}{l}10.27 \\
(4.7)\end{array}$ & $\begin{array}{l}11.52 \\
(4.2)\end{array}$ & $\begin{array}{l}11.35 \\
(4.7)\end{array}$ & $\begin{array}{l}8.72 \\
(5.4)\end{array}$ & $\begin{array}{c}10.99 \\
(5.7)\end{array}$ & $\begin{array}{c}12.69 \\
(3.9)\end{array}$ \\
\hline \multicolumn{10}{|l|}{ Weekend } \\
\hline Fatigue & $\begin{array}{l}3.86 \\
(4.4)\end{array}$ & $\begin{array}{c}6.43 \\
(3.3)\end{array}$ & $\begin{array}{l}8.71 \\
(5.6)\end{array}$ & $\begin{array}{l}9.71 \\
(5.9)\end{array}$ & $\begin{array}{l}8.50 \\
(5.0)\end{array}$ & $\begin{array}{l}8.35 \\
(5.1)\end{array}$ & $\begin{array}{c}12.36 \\
(6.7)\end{array}$ & $\begin{array}{l}6.21 \\
(5.3)\end{array}$ & $\begin{array}{l}6.68 \\
(5.5)\end{array}$ \\
\hline sleepiness & $\begin{array}{l}4.29 \\
(4.9)\end{array}$ & $\begin{array}{l}6.62 \\
(4.9)\end{array}$ & $\begin{array}{l}9.86 \\
(6.2)\end{array}$ & $\begin{array}{l}10.38 \\
(5.6)\end{array}$ & $\begin{array}{l}8.19 \\
(5.3)\end{array}$ & $\begin{array}{l}8.81 \\
(4.8)\end{array}$ & $\begin{array}{c}13.92 \\
(6.1)\end{array}$ & $\begin{array}{l}8.00 \\
(5.6)\end{array}$ & $\begin{array}{l}7.49 \\
(5.4)\end{array}$ \\
\hline Attention & $\begin{array}{l}11.21 \\
(6.6)\end{array}$ & $\begin{array}{l}11.29 \\
(4.1)\end{array}$ & $\begin{array}{l}13.00 \\
(3.9)\end{array}$ & $\begin{array}{l}9.96 \\
(4.5)\end{array}$ & $\begin{array}{l}11.12 \\
(4.3)\end{array}$ & $\begin{array}{c}12.23 \\
(4.3)\end{array}$ & $\begin{array}{l}5.91 \\
(5.9)\end{array}$ & $\begin{array}{c}14.26 \\
(4.1)\end{array}$ & $\begin{array}{c}13.62 \\
(3.9)\end{array}$ \\
\hline State of Alertness & $\begin{array}{c}10.50 \\
(6.6)\end{array}$ & $\begin{array}{c}10.86 \\
(4.3)\end{array}$ & $\begin{array}{c}12.14 \\
(4.3)\end{array}$ & $\begin{array}{l}9.77 \\
(5.4)\end{array}$ & $\begin{array}{l}11.19 \\
(4.4)\end{array}$ & $\begin{array}{l}11.96 \\
(4.5)\end{array}$ & $\begin{array}{l}5.41 \\
(5.9)\end{array}$ & $\begin{array}{l}12.92 \\
(5.2)\end{array}$ & $\begin{array}{c}12.91 \\
(4.9)\end{array}$ \\
\hline
\end{tabular}




\section{Sleep Behavioral Personality Traits Dimensions}

Figure 1 shows that all the subjects had higher scores for the agreeableness personality trait and lower scores for neuroticism. The variance multivariate analysis (MANOVA) showed significant difference among the chronotypes and personality traits $[\lambda=0.78 ; F(10.198)=$ $\left.2.52 ; p<.05 ; \eta^{2}=0.11\right]$. Significant difference was observed only for the traits of extroversion $\left[F(2.103)=3.65 ; p<.05 ; \eta^{2}=0.06\right]$ and agree- ableness $\left[F(2.103)=8.03 ; p<.05 ; \eta^{2}=0.14\right]$. The post hoc Bonferroni test showed that subjects with chronotype I had higher scores in the traits extroversion and agreeableness than $\mathrm{ME}$ subjects $(p<.05)$. Furthermore, the data show that $\mathrm{MM}$ subjects presented higher scores in trace agreeableness than ME subjects $(p<.05)$. However, there were no alterations between the data when the covariates were controlled: wake up time and sleep time in business and non-business days of the week, sleep quality and the dimensions of the visual analogue scale $(p>.05)$.

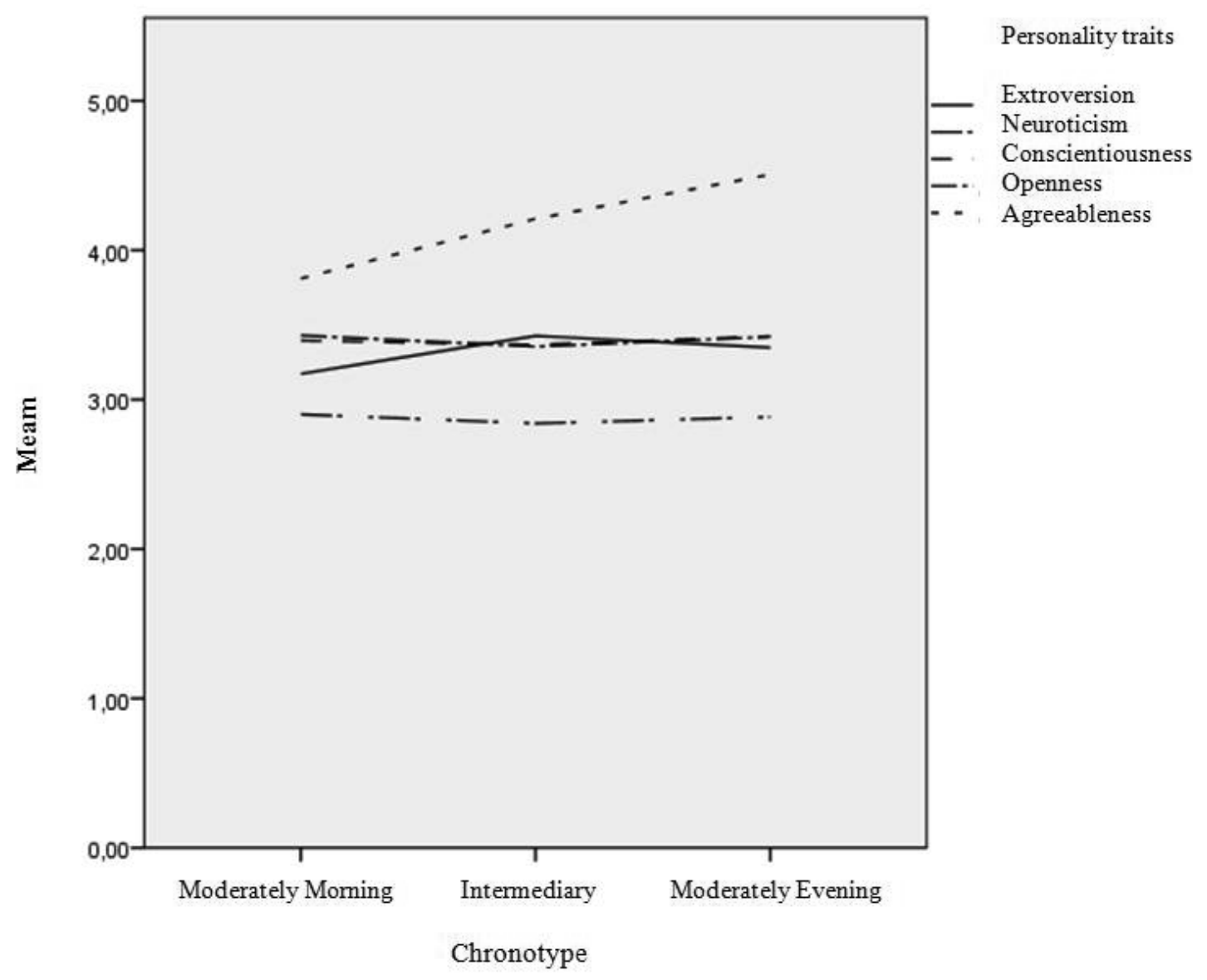

Figure 1. Values of personality traits according to the chronotype.

It was also performed a MANOVA on the data according to the participants' sex (Figure 2 ). Women and men had higher scores for the factor agreeableness and lower scores for the neuroticism factor, regardless of the chronotype. The analysis showed no difference among the chronotypes and personality traits to men, however differences were observed among women $\left[\lambda=0.74 ; F(10.134) ; p<.005 ; \eta^{2}=0.14\right]$ in relation to the trace agreeableness $[F(2.71)=7.74$; $\left.p<.05 ; \eta^{2}=0.18\right]$. MM women showed higher scores regarding agreeableness than $\mathrm{M}$ women. 
A

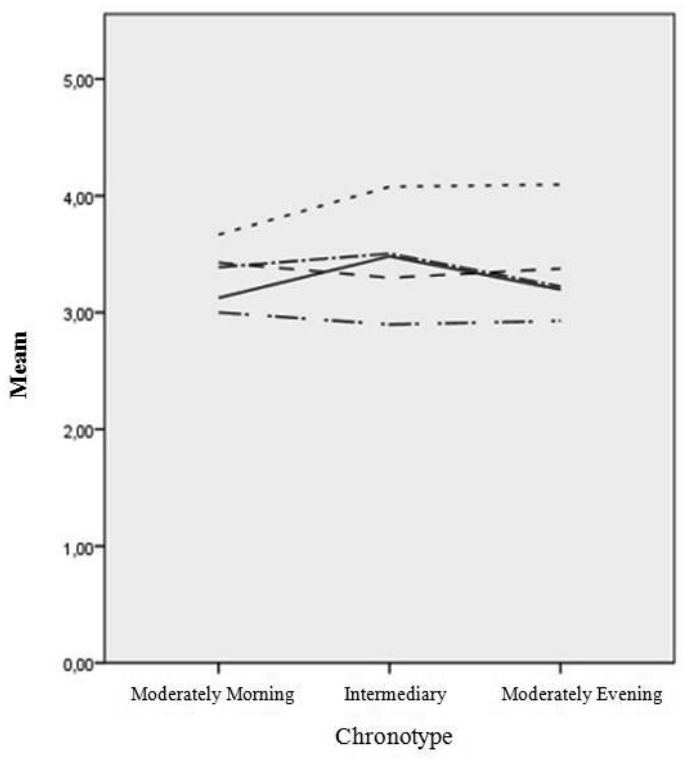

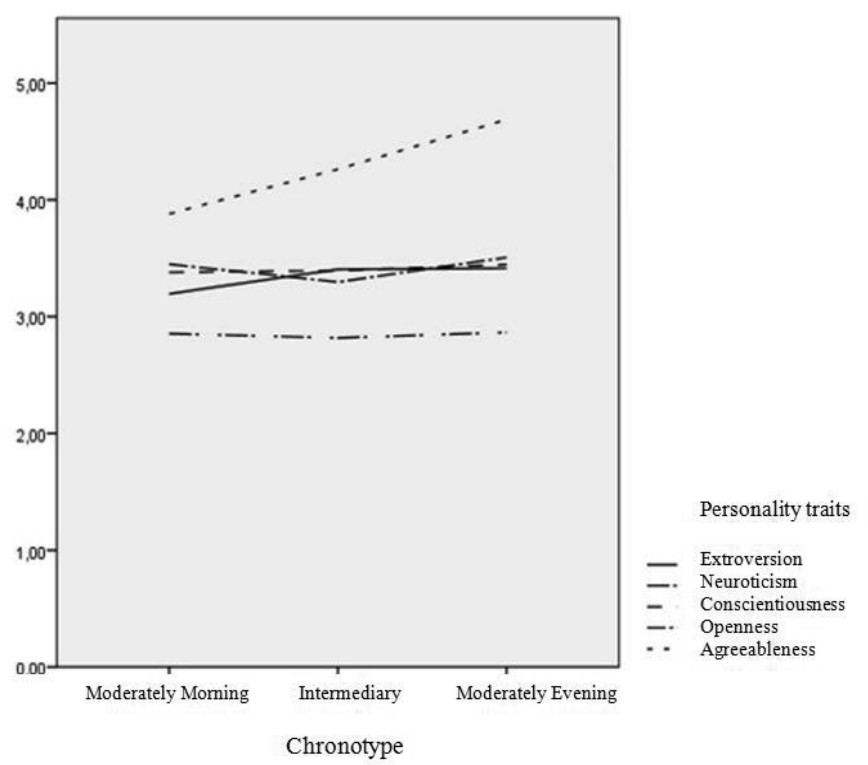

Figure 2. Values of personality traits according to the chronotype and sex. A (Men) and B (Women).

The data analysis showed no significant difference between the personality traits and the women's and men' chronotypes when controlled the sleep behavioral, the dimensions of attention, state of alertness, fatigue, stress and sleep quality of the participants $(p>.05)$. It is possible to verify, also, that there was no difference between the personality traits and the chronotype patterns between genders (i.e., men and women $\mathrm{MM}[p=$ $.46], \mathrm{I}[p=.40]$ and $\mathrm{ME}[p=.83])$.

\section{Discussion}

The objective of this study was to verify the influence of sleep behavioral patterns in the personality traits of men and women having as base the model of the Big Five personality factors (i.e., to verify the influence of chronotype in the analysis of the terms of the language that subjects use to describe themselves and others in their environment; Jonh \& Srivastava, 1999).

According to the criteria of analysis in the chronobiology there were temporal characteristics of the cycle wakefulness-sleep involved in the structure of the biological clock of the research participants, as for example, the chronotype, characteristics of sleep quality, use of psychotropic, neurological disturbances and environmental characteristics (Blatter \& Cajochen, 2007; Portaluppi, Smolensky, \& Touitou, 2010). The subjects presented a well-defined chronotype pattern, being classified as Moderately Morning, intermediary and mode-rately Evening. It is common for most of the population to have an intermediary chronotype, especially among young adults (Preckel, Lipnevich, Schneider, \& Roberts, 2011; Randler, 2007).

When verifying the subject differences concerning the chronotypes, it was realized that even with equivalent durations of sleep, it was possible to confirm the results found by Horne and Östberg (1975). Moderately morning subjects $(\mathrm{MM})$ were those who feel more willing to perform activities in the morning period whilst the Moderately Evening (ME) feel more willing during the night. Significant differences were also identified between sleep time and wake-up time of MM and ME chronotypes.

It is noticed the influence of social zeitgebers on behavior variation according to business and non-business days of the week. According to Delattre (2004), the zeitgebers refer to cyclical variations in environmental factors capable of influencing the rhythm expressions. As seen in the present study, preferences for performing daily activities according to time and days of the 
week can be a functional synchronizer of personality factors. From this perspective, the chronotypes are considered probable dimensions of personality due to the sleep patterns vary individually and have concrete stability, besides being made by genetic factors and exogenous factors (Randread et al., 2014).

It is possible to notice that the subjects I and MM had higher scores in agreeableness and extroversion than ME subjects, respectively. This study described that people with different traits of personalities have specific hours to perform their activities and that there is an association with the pattern of sleep behavioral preference (Cavallera \& Giudici, 2007; Díaz-Morales et al., 2007; Horne \& Östberg, 1977; Mecacci, Righi, \& Rocchetti, 2004; Mecacci et al., 1986; Neubauer, 1992; Schubert \& Randler, 2008; Tankova et al., 1994; Vollmer \& Randler, 2012). Still, subjects with night habits that had higher scores in extroversion and agreeableness, traits which are characterized by less cold and rude behaviors, and with more skills to adapt to the rules of a group to which they belong, demonstrated to be more active and enthusiastic.

Some studies point to the existence of correlation between extroversion and eveningness, suggesting that subjects who consume more caffeine tend to maintain an active night lifestyle, and also that extrovert people have lower basal levels of stimulation than the introvert ones, which would explain the use of stimulants in order to attain a level of stimulation (Adan, Prat, Fabbri, \& Sànchez-Turet, 2008; Kerkhof, 1985; Mitchell \& Redman, 1993). However, the present study indicates that despite of the occasional consumption of caffeine, nicotine and alcohol in the sample, no associations were observed among the chronotypes and consumption of such substances. It is possible that these substances do not result in serious behavioral alterations in personality traits associated with the sleep factor, regardless of the participants' sex. However, it is necessary to carry out studies of psychophysiological measures of cortisol and melatonin to verify the stimulating/inhibitory effects in the central nervous system associated with sleep patterns and personality traits (Bueno \& Way, 2012; Miguel, 2012; Owsley, Sekuler, \& Siemsen, 1983; Paine, Gander, \& Travier, 2006).

Neubauer (1992) when comparing the same factors investigated in the present study, found low correlations, however significant differences between extroversion and neuroticism with the chronotype moderately evening, indicating that moderately evening subjects have characteristics such as enthusiasm, haughtiness, (examples of extroversion) and tendency to present negative states (example of neuroticism). In other studies, the trend of correlation between eveningness and extroversion also appeared as the main correlation (Horne \& Östberg, 1977; Hsu, Gau, Shang, Chiu, \& Lee, 2012; Tankova et al., 1994). Thus, it is observed that even with some difference in results, studies have a significant difference between the extroversion and eveningness traits.

Regarding the degree of fatigue and Sleepiness, both MM women and men proved to be more willing in the morning and unwilling at night, while the ME were more tired in the morning than in the evening. The same can be observed concerning the state of alertness and Attention only among women, because when comparing these factors among $\mathrm{ME}$ and $\mathrm{MM}$ men, there were no great means differences. Therefore, comparing the results obtained in this study with the literature, it is noticed that women exhibit a more sensitive pattern to the state of alertness and vigor (Adan \& Sánchez-Turet, 2001).

It is important to highlight the relevance of replications of this study. However, considering that the environmental variation in the light intensity is able to cause variations in neurocognitive and psychological measures in circadian rhythms (Besílio et al., 2012; Blatter \& Cajochen, 2007; Marques \& Menna-Barreto, 1997; Pereira, Sabino, \& Umemura, 2012), it is necessary to characterize geographically the location of the research subjects, as well as their subject characteristics as performed in this study. Another important point is to characterize the participants regarding a greater $n$ sampling and psychological variations of emotional states. 


\section{Final Considerations}

The circadian sleep patterns are able to change behavioral and neurocognitive measures, as for example, attentional and mnemonic responses. However, it is possible that the preferences to perform daily activities are associated to the dimensions of personality. The present study found differences in personality traits of men and women related to chronotype. It is important to consider that all participants in this study were university students (feature changes in social behavioral patterns according to the academic needs) and are located geographically to “ $07^{\circ} 07^{\prime} 10.19$ " S latitude and longitude $34^{\circ} 50^{\prime}$ ' 42.04" with an amplitude of 43.02 (i.e. the photic density is capable of being associated with these functional mechanisms).

\section{References}

Adan, A., \& Sánchez-Turet, M. (2001). Gender differences in diurnal variations of subjective activation and mood. Chronobiology International, 18(3), 491-502. doi:10.1081/CBI-100103971

Adan, A., Prat, G., Fabbri, M., \& Sànchez-Turet, M. (2008). Early effects of caffeinated and decaffeinated coffee on subjective state and gender differences. Progress in Neuro-Psychopharmacology and Biological Psychiatry, 32(7), 16981703. doi:10.1016/j.pnpbp.2008.07.005

Andrade, J. M. (2008). Evidências de Validade do Inventário dos Cinco Grandes Fatores de Personalidade para o Brasil (Doctoral dissertation, Universidade Federal de Brasília, DF, Brazil).

Benedito-Silva, A. A., Menna-Barreto, L., Marques, N., \&Tenreiro, S. (1990). A self-assessment questionnaire for the determination of morningness-eveningness types in Brazil. Progress in Clinical and Biological Research, 341, 89-98.

Besílio, A. S., Carneiro, B. T., Silva, C. A., Fortes, F. S., \&Araújo, J. F. (2012). Métodos cronobiológicos aplicados à neurociência clínica e experimental. Métodos em Neurociências, 114127.

Blatter, K., \& Cajochen, C. (2007). Circadian rhythms in cognitive performance: Methodological constraints, protocols, theoretical underpinnings. Physiology \& Behavior, 90(2), 196-208. doi:10.1016/j.physbeh.2006.09.009
Bueno, C., \& Way, D. (2012). Gênese e ontogênese do ritmo de sono/vigília em humanos. Revista de Biologia, 9(3), 62-67. doi:10.7594/ revbio.09.03.12

Cavallera, G. M., \& Giudici, S. (2007). Morningness and eveningness personality: A survey in literature from 1995 up till 2006. Personality and Individual Differences, 44(1), 3-21. doi:10.1016/j.paid.2007.07.009

Cunha, J. A. (1999). Estudo dos pontos de corte do BDI e do BAI na versão em Português [Abstract]. In VIII Congresso Nacional de Avaliação Psicológica (p. 78). Porto Alegre, RS.

Delattre, E. (2004). Ritmos hormonais do pâncreas endócrino: Dos fundamentos cronobiológicos às implicações clínicas. Medicina, 37, 51-64.

DeYoung, C. G., Hasher, L., Djikic, M., Criger, B., \& Peterson, J. B. (2007). Morning people are stable people: Circadian rhythm and the higher-order factors of the Big Five. Personality and Individual Differences, 43(2), 267-276. doi:10.1016/j.paid.2006.11.030

Díaz-Morales, J. F., de León, M. C. D., \& Sorroche, M. G. (2007). Validity of the morningness-eveningness scale for children among Spanish adolescents. Chronobiology International, 24(3), 435-447. doi:10.1080/07420520701420659

Duggan, K. A., Friedman, H. S., McDevitt, E. A., \& Mednick, S. A. (2014). Personality and Healthy Sleep: The Importance of Conscientiousness and Neuroticism. PLOSone, 9(3), 1-11.

Furlani, R., \& Ceolim, M. F. (2005). Padrões de sono de estudantes ingressantes na Graduação em Enfermagem. Revista Brasileira de Enfermagem, 58(3), 320-324. doi:10.1590/S003471672005000300013

Horne, J. A., \& Östberg, O. (1975). A self-assessment questionnaire to determine morningness-eveningness in human circadian rhythms. International Journal of Chronobiology, 4(2), 97-110.

Horne, J. A., \& Östberg, O. (1977). Individual differences in human circadian rhythms. Biological Psychology, 5(3), 179-190.

Hsu, C. Y., Gau, S. S. F., Shang, C. Y., Chiu, Y. N., \& Lee, M. B. (2012). Associations between chronotypes, psychopathology, and personality among incoming college students. Chronobiology International, 29(4), 491-501. doi:10.3109/ 07420528.2012 .668995 
Jackson, L. A., \& Gerard, D. A. (1996). Diurnal types, the" Big Five" personality factors, and other personal characteristics. Journal of Social Behavior and Personality, 11(2), 273.

John, O. P., \& Srivastava, S. (1999). The Big Five trait taxonomy: History, measurement, and theoretical perspectives. Handbook of Personality: Theory and Research, 2(1999), 102-138.

Kerkhof, G. A. (1985). Inter-individual differences in the human circadian system: A review. Biological Psychology, 20(2), 83-112. doi:10.1016/03010511(85)90019-5

Laneiro, T., Brites, R., Tap, P., Silva, A., Reguinga, O., \& Guerra, S. (2011). A influência da alteração dos ciclos circadianos na auto-percepção individual: A experiência subjectiva de fadiga, atenção, tensão e satisfação na tarefa. Psicologia, Saúde \& Doenças, 12(1), 3-17.

Larsen, R. J. (1985). Individual differences in circadian activity rhythm and personality. Personality and Individual Differences, 6(3), 305-311. doi:10.1016/0191-8869(85)90054-6

Marques, N., \& Menna-Barreto, L. (1997). Cronobiologia: Princípios e Aplicacões: Vol. 12. São Paulo, SP: Editora da Universidade de São Paulo.

Mecacci, L., Righi, S., \& Rocchetti, G. (2004). Cognitive failures and circadian typology. Personality and Individual Differences, 37(1), 107-113. doi:10.1016/j.paid.2003.08.004

Mecacci, L., Zani, A., Rocchetti, G., \& Lucioli, R. (1986). The relationships between morningnesseveningness, ageing and personality. Personality and Individual Differences, 7(6), 911-913. doi:10.1016/0191-8869(86)90094-2

Miguel, M. A. L. (2012). Estimativa de tempo em humanos: Bases, ontogênese e variação diária. Revista de Biologia, 9(3), 74-79. doi:10.7594/ revbio.09.03.14

Mitchell, P. J., \& Redman, J. R. (1993). The relationship between morningness-eveningness, personality and habitual caffeine consumption. Personality and Individual Differences, 15(1), 105-108. doi:10.1016/0191-8869(93)90050-D

Neubauer, A. C. (1992). Psychometric comparison of two circadian rhythm questionnaires and their relationship with personality. Personality and Individual Differences, 13(2), 125-131. doi:10.1016/0191-8869(92)90035-N
Owsley, C., Sekuler, R., \& Siemsen, D. (1983). Contrast sensitivity throughout adulthood. Vision Research, 23, 689-699.

Paine, S. J., Gander, P. H., \& Travier, N. (2006). The epidemiology of morningness/eveningness: Influence of age, gender, ethnicity, and socioeconomic factors in adults (30-49 years). Journal of Biological Rhythms, 21(1), 68-76. doi:10.1177/0748730405283154

Pereira, D. S., Sabino, F. C., \& Umemura, G. S. (2012). Period3: Um gene relacionado com asincronização de ritmos circadianos pela luz. Revista de Biologia, 9(3), 26-31. doi:10.7594/ revbio.09.03.05

Portaluppi, F., Smolensky, M. H., \& Touitou, Y. (2010). Ethics and methods for biological rhythm research on animals and human beings. Chronobiology International, 27(9-10), 19111929. doi:10.3109/07420528.2010.516381

Preckel, F., Lipnevich, A. A., Schneider, S., \& Roberts, R. D. (2011). Chronotype, cognitive abilities, and academic achievement: A metaanalytic investigation. Learning and Individual Differences, 21(5), 483-492. doi:10.1016/j.lindif.2011.07.003

Randler, C. (2007). Gender differences in morningness-eveningness assessed by self-report questionnaires: A meta-analysis. Personality and Individual Differences, 43(7), 1667-1675. doi:10.1016/j.paid.2007.05.004

Randler, C., Baumann, V. P., \& Horzum, M. B. (2014). Morningness-eveningness, Big Five and the BIS/BAS inventory. Personality and Individual Differences, 66, 64-67. doi:10.1016/j. paid.2014.03.010

Randler, C., \& Saliger,L.(2011). Relationship between morningness-eveningness and temperament and character dimensions in adolescents. Personality and Individual Differences, 50(2), 148-152. doi:10.1016/j.paid.2010.09.016

Roenneberg, T., Kuehnle, T., Pramstaller, P. P., Ricken, J., Havel, M., Guth, A., \& Merrow, M. (2004). A marker for the end of adolescence. Current Biology, 14(24), 1038. doi:10.1016/j. cub.2004.11.039

Russo, P. M., Leone, L., Penolazzi, B., \& Natale, V. (2012). Circadian preference and the big five: The role of impulsivity and sensation seeking. Chronobiology International, 29(8), 1121-1126. doi:10.3109/07420528.2012.706768 
Schubert, E., \& Randler, C. (2008). Association between chronotype and the constructs of the ThreeFactor-Eating-Questionnaire. Appetite, 51(3), 501-505. doi:10.1016/j.appet.2008.03.018

Tankova, I., Adan, A., \& Buela-Casal, G. (1994). Circadian typology and individual differences. A review. Personality and Individual Differences, 16(5), 671-684. doi:10.1016/01918869(94)90209-7

Tonetti, L., Adan, A., Caci, H., De Pascalis, V., Fabbri, M., \& Natale, V. (2010). Morningnesseveningness preference and sensation seeking. European Psychiatry, 25(2), 111-115. doi:10.1016/j.eurpsy.2009.09.007

Torsvall, L., \& Åkerstedt, T. (1980). A diurnal type scale: Construction, consistency and validation in shift work. Scandinavian Journal of Work, Environment \& Health, 283-290. doi:10.5271/ sjweh. 2608
Valdez, P., Ramirez, C., \& Garcia, A. (2012). Circadian rhythms in cognitive performance: Implications for neuropsychological assessment. Chrono Physiology and Terapy, 2, 81-82. doi:http:// dx.doi.org/10.2147/CPT.S32586

Vollmer, C., \& Randler, C. (2012). Circadian preferences and personality values: Morning types prefer social values, evening types prefer individual values. Personality and Individual Differences, 52(6), 738-743. doi:10.1016/j.paid.2012.01.001

Received: 03/07/2016

$1^{\text {st }}$ revision: $26 / 12 / 2016$

Accepted: 21/02/2017

(C) The Author(s), 2018. Open Access. This article is distributed under the terms of the Creative Commons Attribution 4.0 International License (http://creativecommons.org/licenses/by/4.0/), which permits unrestricted use, distribution, and reproduction in any medium, provided you give appropriate credit to the original author(s) and the source, provide a link to the Creative Commons license, and indicate if changes were made. 